\title{
INTERNATIONAL RESEARCH JOURNAL OF PHARMACY
}

www.irjponline.com

ISSN $2230-8407$

\section{Research Article}

\section{STUDIES ON IMPACT OF CYPERMETHRIN ON ACID AND ALKALINE PHOSPHATASE ACTIVITY IN THE SELECTED ORGANS OF FRESH WATER FISH CIRRHINUS MRIGALA (HAMILTON) AND THE PROTECTIVE EFFECT OF CARDIOSPERMUM HALICACABUM}

Vasantharaja C, K. Pugazhendy*, M. Meenambal

Department of Zoology, Annamalai University, Annamalainagar, Tamil Nadu, India

*Corresponding Author Email: avmowleemeena@gmail.com

Article Received on: 29/07/14 Revised on: 05/08/14 Approved for publication: 26/08/14

\section{DOI: 10.7897/2230-8407.0509136}

\section{ABSTRACT}

The impact of cypermethrin on acid phosphatase (ACP) and alkaline phosphatase (ALP) activity in gill, liver and kidney on Cirrhinus mrigala, exhibited notable alterations which are being the main site of metabolic activity in fish. The acute toxicity value was found to be $150 \mu \mathrm{g} / \mathrm{l}$ and $1 / 5$ as used for $\mathrm{LC}_{50}(30$ $\mu \mathrm{g} / \mathrm{l}$ ) was selected for sub lethal concentration. The ACP and ALP values in all the organs were decreased due to 120 hours treatment of cypermethrin. These enzymes in various organs were recovered by Cardiospermum halicacabum. Hence the pesticide intoxication has made a disturbance in normal function of cells.

Keywords: Cypermethrin, Cirrhinus mrigala, Cardiospermum halicacabum, ACP and ALP

\section{INTRODUCTION}

Due to industrialization and human population, the pollution of aquatic ecosystem has become a universal phenomenon in the present day ${ }^{1}$. The main sources of water pollution are industrial waste, domestic sewage, drainage and pesticides used for food production ${ }^{2}$. The synthetic pyrethroids, a new generation insecticides are synthesized derivatives of naturally occurring pyrethrins, taken from pyrethrum, the oleoresin extract of genus Chrysanthemum flowers. They are more effective than the organophosphate pesticides, replacing them in many agricultural, commercial and residential applications. Due to lipophilic nature, biological membranes and tissues readily take those ${ }^{3}$. Fish may be good indicators of contamination by pollutants because their biochemical responses are quite similar to those found in mammals ${ }^{4}$. According to ${ }^{5}$, biochemical changes occurs in fishes that are exposed to environmental contaminants, such changes may include pesticides and their metabolites have necessitated a number of studies to determine their effects in aquatic environment on biochemical parameters in fish ${ }^{6}$. Several authors have investigated the effect of pesticide in fish ${ }^{6-8,4}$. The ACP and ALP are active at specific pH and are usually termed phosphomonoesterases. Pesticide poisoning increases ACP and ALP activity in the fish ${ }^{9}$. The ACP is a lysosomal enzyme and the raise in its activity is probably related to the cellular damage. It is difficult, however, to relate the decrease in ACP activity with necrosis. Increase in acid phosphatase and alkaline phosphatase activities can be interpreted as a shift, which emphasise on energy break down pathway from normal ATPase system which includes phosphorylation ${ }^{10}$. The plant-based, traditional medicine systems continues to play an essential role in health care, with about $80 \%$ of the world's inhabitants relying mainly on traditional medicines for their primary health care ${ }^{11}$. Medicinal plants produce bioactive compounds used mainly for medicinal purposes. These compounds either act on different systems of animals including man and or act through interfering in the metabolism. So the identification of bioactive compound in plants, their isolation, purification and characterization of active ingredients in crude extracts by various analytical methods is important. The medicinal properties of plants could be based on the antioxidant, antimicrobial, antipyretic effects of the phytochemicals in them ${ }^{12}$. Hence an attempt has been made to investigate the toxic impact of cypermethrin on ACP and ALP activity in the C. mrigala and also recovery activity observed by $C$. halicacabum exposed animals.

\section{MATERIALS AND METHODS}

The fish Cirrhinus mrigala of size 14 to $16 \mathrm{~cm}$ and 50 to $70 \mathrm{~g}$ weight were brought from a local fish farm in Pinnaloor, at Navarathna form. Fish collected and acclimatized at $28^{\circ} \mathrm{C}$ in the large sized aquarium tank disinfected with potassium permanganate and washed thoroughly prior to conduction of fish to prevent the fungal disease for acclimatization in the laboratory condition for 15 days. During laboratory condition fishes were feed with artificial feed, water was renewed on every day to maintain water quality. The $\mathrm{LC}_{50}$ concentration of cypermethrin was noted at $120 \mathrm{~h}$; fish organs (gill, liver and kidney) were collected by dissection the animal and stored at $-20^{\circ} \mathrm{C}$ for enzymes parameters studies. Fishes were exposed in 4 groups.

Group-1 fish exposed to tap water (control)

Group- 2 fish exposed to cypermethrin

Group-3 Fish exposed to cypermethrin along with Cardiospermum halicacabum

Group-4 Fish exposed to Cardiospermum halicacabum alone

\section{Plant Preparation}

Healthy disease free leaves of Cardiospermum halicacabum were collected from Villupuram district Nallavur Village in January-2011 and plant was identified. The leaf were washed in running tap water for 10 minutes then leafs were dried, aerial parts $(1 \mathrm{~kg})$ of Cardiospermum halicacabum were macerated thrice at room temperature and prepared in powdered condition and equal amount of rice brane powder mixed well and small amount water added and prepared small pellet as feed. 


\section{Enzymes Assay}

The acid phosphatase (ACP) and alkaline phosphatase (ALP) were estimated by using the method of ${ }^{13}$.

\section{Statistically Analyses}

The data obtained in the present work were expressed as means $\pm \mathrm{SE}$, percentage changes and were statistically analyzed using student $t$-test ${ }^{14}$, to compare means of treated data against their control ones and the result were considered significant at $(\mathrm{P}<0.05),(\mathrm{P}<0.01)$ level.

Table 1: Variations of acid phosphatase (ACP) ( $\mu$ mole/min/mg protein) activity in the freshwater fish $C$. mrigala exposed to cypermethrin and $C$. halicacabum for 120 hours

\begin{tabular}{|c|c|c|c|c|c|c|}
\hline \multirow[t]{2}{*}{ Tissues } & \multirow[t]{2}{*}{ Groups } & \multicolumn{5}{|c|}{ Hours of exposure } \\
\hline & & 24 & 48 & 72 & 96 & 120 \\
\hline \multirow[t]{4}{*}{ Gill } & Group-I Control & $2.030 \pm 0.028$ & $2.033 \pm 0.032$ & $2.037 \pm 0.037$ & $2.035 \pm 0.026$ & $2.033 \pm 0.020$ \\
\hline & $\begin{array}{c}\text { Group-II CYP } \\
\% \text { COC }\end{array}$ & $\begin{array}{c}1.858 * * \pm 0.023 \\
\%-8.47\end{array}$ & $\begin{array}{c}1.651 * * \pm 0.048 \\
\%-18.79\end{array}$ & $\begin{array}{c}1.485 * * \pm 0.037 \\
\%-27.10\end{array}$ & $\begin{array}{c}1.316^{* *} \pm 0.069 \\
\%-35.33\end{array}$ & $\begin{array}{c}1.256 * * \pm 0.032 \\
\%-38.22\end{array}$ \\
\hline & $\begin{array}{c}\text { Group-III CYP }+C . \text { halicacabum } \\
\% \text { COC } \\
\% \text { COT }\end{array}$ & $\begin{array}{c}1.909^{\mathrm{NS}} \pm 0.048 \\
\%-5.96 \\
\%+2.74\end{array}$ & $\begin{array}{c}1.855 * \pm 0.042 \\
\%-8.75 \\
\%+12.36\end{array}$ & $\begin{array}{c}1.823 * \pm 0.068 \\
\%-10.50 \\
\%+22.76\end{array}$ & $\begin{array}{c}1.798 * * \pm 0.027 \\
\%-11.65 \\
\%+36.63\end{array}$ & $\begin{array}{c}1.750 * * \pm 0.035 \\
\%-13.92 \\
\%+39.33\end{array}$ \\
\hline & $\begin{array}{c}\text { Group-IV C. halicacabum } \\
\% \text { COC }\end{array}$ & $\begin{array}{c}2.036^{\mathrm{NS}} \pm 0.046 \\
\%+0.29\end{array}$ & $\begin{array}{c}2.044^{\mathrm{NS}} \pm 0.032 \\
\%+0.54\end{array}$ & $\begin{array}{c}2.055^{\mathrm{NS}} \pm 0.048 \\
\%+0.88\end{array}$ & $\begin{array}{c}2.061^{\mathrm{NS}} \pm 0.027 \\
\%+1.28\end{array}$ & $\begin{array}{c}2.060^{\mathrm{NS}} \pm 0.030 \\
\%+1.33\end{array}$ \\
\hline \multirow[t]{4}{*}{ Liver } & Group-I Control & $3.116 \pm 0.040$ & $3.120 \pm 0.031$ & $3.122 \pm 0.029$ & $3.120 \pm 0.035$ & $3.118 \pm 0.022$ \\
\hline & $\begin{array}{c}\text { Group-II CYP } \\
\% \text { COC }\end{array}$ & $\begin{array}{c}2.921 * * \pm 0.022 \\
\%-6.26\end{array}$ & $\begin{array}{c}2.736 * * \pm 0.044 \\
\%-12.31\end{array}$ & $\begin{array}{c}2.518 * * \pm 0.030 \\
\%-19.35\end{array}$ & $\begin{array}{c}2.404 * * \pm 0.034 \\
\%-22.95\end{array}$ & $\begin{array}{c}2.298 * * \pm 0.068 \\
\%-26.30\end{array}$ \\
\hline & $\begin{array}{c}\text { Group-III CYP }+C \text {. halicacabum } \\
\% \text { COC } \\
\% \text { COT } \\
\end{array}$ & $\begin{array}{c}2.989 * \pm 0.022 \\
\%-4.07 \\
\%+2.33 \\
\end{array}$ & $\begin{array}{c}2.915 * * \pm 0.045 \\
\%-6.57 \\
\%+6.54 \\
\end{array}$ & $\begin{array}{c}2.870 * * \pm 0.038 \\
\%-8.07 \\
\%+13.98 \\
\end{array}$ & $\begin{array}{c}2.834 * * 0.027 \\
\%-9.17 \\
\%+17.89 \\
\end{array}$ & $\begin{array}{c}2.801 * * \pm 0.040 \\
\%-10.17 \\
\%+21.89\end{array}$ \\
\hline & $\begin{array}{c}\text { Group-IV C. halicacabum } \\
\% \text { COC }\end{array}$ & $\begin{array}{c}3.124^{\mathrm{NS}} \pm 0.037 \\
\%+0.26\end{array}$ & $\begin{array}{c}3.135^{\mathrm{NS}} \pm 0.028 \\
\%+0.48\end{array}$ & $\begin{array}{c}3.147^{\mathrm{NS}} \pm 0.040 \\
\%+0.80\end{array}$ & $\begin{array}{c}3.151^{\mathrm{NS}} \pm 0.068 \\
\%+0.99\end{array}$ & $\begin{array}{c}3.155^{\mathrm{NS}} \pm 0.026 \\
\%+1.19\end{array}$ \\
\hline \multirow[t]{4}{*}{ Kidney } & Group-I Control & $4.246 \pm 0.066$ & $4.249 \pm 0.048$ & $4.251 \pm 0.070$ & $4.250 \pm 0.071$ & $4.248 \pm 0.056$ \\
\hline & $\begin{array}{c}\text { Group-II CYP } \\
\% \text { COC }\end{array}$ & $\begin{array}{c}3.798 * * \pm 0.047 \\
\%-10.55\end{array}$ & $\begin{array}{c}3.543 * * \pm 0.066 \\
\%-16.61\end{array}$ & $\begin{array}{c}3.325 * * \pm 0.052 \\
\%-21.78\end{array}$ & $\begin{array}{c}3.109 * * \pm 0.047 \\
\%-26.85\end{array}$ & $\begin{array}{c}2.987 * * \pm 0.027 \\
\%-29.68\end{array}$ \\
\hline & $\begin{array}{c}\text { Group-III CYP }+ \text { C. halicacabum } \\
\% \text { COC } \\
\% \text { COT }\end{array}$ & $\begin{array}{c}3.996 * \pm 0.038 \\
\%-5.89 \\
\%+5.21\end{array}$ & $\begin{array}{c}3.883 * * \pm 0.066 \\
\%-8.61 \\
\%+9.60\end{array}$ & $\begin{array}{c}3.817 * * \pm 0.024 \\
\%-10.21 \\
\%+14.80\end{array}$ & $\begin{array}{c}3.764 * * \pm 0.050 \\
\%-11.43 \\
\%+21.07\end{array}$ & $\begin{array}{c}3.695 * \pm 0.031 \\
\%-13.02 \\
\%+23.70\end{array}$ \\
\hline & $\begin{array}{c}\text { Group-IV C. halicacabum } \\
\% \text { COC }\end{array}$ & $\begin{array}{c}4.256^{\mathrm{NS}} \pm 0.061 \\
\%+0.23\end{array}$ & $\begin{array}{c}4.260^{\mathrm{NS}} \pm 0.071 \\
\%+0.26\end{array}$ & $\begin{array}{c}4.276^{\mathrm{NS}} \pm 0.056 \\
\%+0.59\end{array}$ & $\begin{array}{c}4.280^{\mathrm{NS}} \pm 0.068 \\
\%+0.70\end{array}$ & $\begin{array}{c}4.285^{\mathrm{NS}} \pm 0.048 \\
\%+0.87\end{array}$ \\
\hline
\end{tabular}

Values are mean \pm S.E-Mean of six individual observations; and student t-test, Significant at $* \mathrm{P}<0.05$; Significant at $* * \mathrm{P}<0.01$ levels. $(+,-)$ denotes decreased and increased, \% COC (change over control); \% COT (change over treated)

Table 2: Variations of alkaline phosphatase (ALP) ( $\mu$ mole/min/mg protein) activity in the freshwater fish $C$. mrigala exposed to cypermethrin and $C$. halicacabum for 120 hours

\begin{tabular}{|c|c|c|c|c|c|c|}
\hline \multirow[t]{2}{*}{ Tissues } & \multirow[t]{2}{*}{ Groups } & \multicolumn{5}{|c|}{ Hours of exposure } \\
\hline & & 24 & 48 & 72 & 96 & 120 \\
\hline \multirow[t]{4}{*}{ Gill } & Group-I Control & $2.353 \pm 0.021$ & $2.358 \pm 0.048$ & $2.361 \pm 0.036$ & $2.355 \pm 0.086$ & $2.351 \pm 0.047$ \\
\hline & $\begin{array}{c}\text { Group-II CYP } \\
\% \text { COC }\end{array}$ & $\begin{array}{c}2.076 * * \pm 0.018 \\
\%-11.77\end{array}$ & $\begin{array}{c}1.870 * * \pm 0.029 \\
\%-20.69\end{array}$ & $\begin{array}{c}1.723 * * \pm 0.046 \\
\%-27.02\end{array}$ & $\begin{array}{c}1.575 * * \pm 0.038 \\
\%-33.12\end{array}$ & $\begin{array}{c}1.423 * * \pm 0.064 \\
\%-39.47\end{array}$ \\
\hline & $\begin{array}{c}\text { Group-III CYP }+ \text { C. halicacabum } \\
\% \text { COC } \\
\% \text { COT }\end{array}$ & $\begin{array}{c}2.192 * * \pm 0.042 \\
\%-6.84 \\
\%+5.59\end{array}$ & $\begin{array}{c}2.157 * \pm 0.021 \\
\%-8.52 \\
\%+15.35\end{array}$ & $\begin{array}{c}2.117 * * \pm 0.036 \\
\%-10.33 \\
\%+22.87\end{array}$ & $\begin{array}{c}2.095 * \pm 0.020 \\
\%-11.04 \\
\%+33.01\end{array}$ & $\begin{array}{c}2.023 * * \pm 0.032 \\
\%-13.95 \\
\%+42.16\end{array}$ \\
\hline & $\begin{array}{c}\text { Group-IV C. halicacabum } \\
\% \text { COC }\end{array}$ & $\begin{array}{c}2.361^{\mathrm{NS}} \pm 0.046 \\
\%+0.34\end{array}$ & $\begin{array}{c}2.370^{\mathrm{NS}} \pm 0.043 \\
\%+0.50\end{array}$ & $\begin{array}{c}2.378^{\mathrm{NS}} \pm 0.037 \\
\%+0.72\end{array}$ & $\begin{array}{c}2.383^{\mathrm{NS}} \pm 0.050 \\
\%+1.19\end{array}$ & $\begin{array}{c}2.380^{\mathrm{NS}} \pm 0.027 \\
\%+1.23\end{array}$ \\
\hline \multirow[t]{4}{*}{ Liver } & Group-I Control & $4.350 \pm 0.056$ & $4.353 \pm 0.059$ & $4.358 \pm 0.077$ & $4.354 \pm 0.044$ & $4.352 \pm 0.062$ \\
\hline & $\begin{array}{c}\text { Group-II CYP } \\
\% \text { COC }\end{array}$ & $\begin{array}{c}3.980 * \pm 0.084 \\
\%-8.50\end{array}$ & $\begin{array}{c}3.767 * * \pm 0.096 \\
\%-13.46\end{array}$ & $\begin{array}{c}3.560 * * \pm 0.086 \\
\%-18.31\end{array}$ & $\begin{array}{c}3.394 * * \pm 0.037 \\
\%-22.05\end{array}$ & $\begin{array}{c}3.153 * * \pm 0.040 \\
\%-27.55\end{array}$ \\
\hline & $\begin{array}{c}\text { Group-III CYP }+ \text { C. halicacabum } \\
\% \text { COC } \\
\% \text { COT } \\
\end{array}$ & $\begin{array}{c}4.143^{\mathrm{NS}} \pm 0.074 \\
\%-4.76 \\
\%+4.09 \\
\end{array}$ & $\begin{array}{c}4.086 * \pm 0.062 \\
\%-6.13 \\
\%+8.47 \\
\end{array}$ & $\begin{array}{c}4.025 * \pm 0.080 \\
\%-7.64 \\
\%+13.06 \\
\end{array}$ & $\begin{array}{c}3.986 * * \pm 0.069 \\
\%-8.45 \\
\%+17.44 \\
\end{array}$ & $\begin{array}{c}3.903 * * \pm 0.069 \\
\%-10.32 \\
\%+23.79\end{array}$ \\
\hline & $\begin{array}{c}\text { Group-IV C. halicacabum } \\
\% \text { COC }\end{array}$ & $\begin{array}{c}4.359^{\mathrm{NS}} \pm 0.045 \\
\%+0.20\end{array}$ & $\begin{array}{c}4.372^{\mathrm{NS}} \pm 0.096 \\
\%+0.44\end{array}$ & $\begin{array}{c}4.384^{\mathrm{NS}} \pm 0.072 \\
\%+0.60\end{array}$ & $\begin{array}{c}4.397^{\mathrm{NS}} \pm 0.055 \\
\%+0.99\end{array}$ & $\begin{array}{c}4.405^{\mathrm{NS}} \pm 0.040 \\
\%+1.22\end{array}$ \\
\hline \multirow[t]{4}{*}{ Kidney } & Group-I Control & $5.818 \pm 0.043$ & $5.821 \pm 0.080$ & $5.824 \pm 0.047$ & $5.822 \pm 0.073$ & $5.821 \pm 0.061$ \\
\hline & $\begin{array}{c}\text { Group-II CYP } \\
\% \text { COC }\end{array}$ & $\begin{array}{c}5.061 * * \pm 0.080 \\
\%-13.01\end{array}$ & $\begin{array}{c}4.683 * * \pm 0.069 \\
\%-19.55\end{array}$ & $\begin{array}{c}4.188 * * \pm 0.032 \\
\%-28.90\end{array}$ & $\begin{array}{c}3.961 * * \pm 0.098 \\
\%-31.96\end{array}$ & $\begin{array}{c}3.604 * * \pm 0.070 \\
\%-38.09\end{array}$ \\
\hline & $\begin{array}{c}\text { Group-III CYP }+ \text { C. halicacabum } \\
\% \text { COC } \\
\% \text { COT }\end{array}$ & $\begin{array}{c}5.490 * * \pm 0.069 \\
\%-5.64 \\
\%+8.48 \\
\end{array}$ & $\begin{array}{c}5.325 * * \pm 0.043 \\
\%-8.52 \\
\%+13.71 \\
\end{array}$ & $\begin{array}{c}5.122 * * \pm 0.030 \\
\%-12.05 \\
\%+22.30 \\
\end{array}$ & $\begin{array}{c}5.033 * * \pm 0.049 \\
\%-13.55 \\
\%+27.06\end{array}$ & $\begin{array}{c}4.936 * * \pm 0.047 \\
\%-15.20 \\
\%+36.96\end{array}$ \\
\hline & $\begin{array}{c}\text { Group-IV C. halicacabum } \\
\% \text { COC }\end{array}$ & $\begin{array}{c}5.828^{\mathrm{NS}} \pm 0.030 \\
\%+0.17\end{array}$ & $\begin{array}{c}5.839^{\mathrm{NS}} \pm 0.076 \\
\%+0.31\end{array}$ & $\begin{array}{c}5.851^{\mathrm{NS}} \pm 0.049 \\
\%+0.46\end{array}$ & $\begin{array}{c}5.870^{\mathrm{NS}} \pm 0.070 \\
\%+0.82\end{array}$ & $\begin{array}{c}5.877^{\mathrm{NS}} \pm 0.084 \\
\%+0.96\end{array}$ \\
\hline
\end{tabular}

Values are mean \pm S.E-Mean of six individual observations; and student t-test, Significant at $* \mathrm{P}<0.05$; Significant at $* * \mathrm{P}<0.01$ levels. $(+,-)$ denotes decreased and increased. \% COC (change over control); \% COT (change over treated) 


\section{RESULT AND DISCUSSION}

Enzymatic analysis of organs such as kidney, liver, and gills in fish can provide important information about the internal environment of the organism ${ }^{15}$. Enzyme activities affect various chemical and biological reactions in the body of the fish $^{16}$. The activity of phosphatase was decreased in the gill, liver and kidney of fish Cirrhinus mrigala treated with cypermethrin. Phosphatases are mainly localized at cell membrane. Any damage in the cell may result in alteration in phosphatases activity. The dose dependent inhibition in the activities of acid and alkaline phosphatases observed in this investigation is in agreement with the report of many other workers $^{17}$. In the present investigation, the acid phosphate content was decreased in the treated group-2 like fish organs followed by period of 24 hours to 120 hours. At the end of the 120 hours the treated (group 2) percentage changes decreased over the control (group-1). ACPlevel gill (-38.22 $\%)$, liver $(-26.30 \%)$ and kidney $(-29.68 \%)$ The fish was exposed to group-3 the ACP content was recovered when compared to group-2 gill (39.33\%), liver $(21.89 \%)$ and kidney $(23.70 \%)$ while in the fish exposed to group-4 when compared to group-1 the slightly increased $(1.33 \%),(1.19$ $\%)$ and $(0.87 \%)$. The recorded acid phosphate content were statistically significant at $5 \%, 1 \%$ levels (Table 1). The decreased activities of ACP indicate disturbance in the structure and integrity of cell organelles like endoplasmic reticulum and membrane transport system $^{18}$, have reported the changes in phosphatase activity in fishes due to exposure to industrial effluents. Similarly ${ }^{19}$, reported depletion of alkaline phosphatase due to sub-lethal exposure of Labeo rohita fingerlings to Cypermethrin. In the alkaline phosphatase investigation, the alkaline phosphatase content was inhibited in the treated group-2 like fish organs followed by period of 24 hours to 120 hours. At the end of the 120 hours the treated group percentage changes are decreased over the control group 1; group-2 ALP level in gill (-39.47 $\%)$, liver $(-27.55 \%)$ and kidney $(-38.09 \%)$. The fish was exposed to group-3 the alkaline phosphatase content was recovered when compared to group-2 (42.16\%), (23.78\%) and $(36.96 \%)$ while in the fish exposed to group-4 when compared to group-1 the slightly increased (1.23\%), (1.22 $\%)$ and $(0.96 \%)$. The recorded alkaline phosphatase content were statistically significant at 5\%,1\% levels (Table 2). The decrease activity of ALP in the various organs may be attributed due to decline in the rate of synthesis caused by lowered metabolic demands and also due to electrolytic imbalance caused by tissue over hydration ${ }^{20}$. The activity of ALP decreased in liver, kidney and gill was recorded in ovary and muscle ${ }^{21}$. The decreased activities of ACP and ALP indicate disturbance in the structure and integrity of cell organelles like endoplasmic reticulum and membrane transport system ${ }^{21}$. They also reported the changes in phosphatases activity in fishes due to exposure to industrial effluents Similarly ${ }^{19}$. The observed reduction in ACP and ALP in the gill and liver of $C$. mrigala treated with cypermethrin. The metabolic pathways of fish are affected by pollutants; Acid phosphatase is a lysosomal enzyme that hydrolyses the phospho-esters in acidic medium. Alkaline phosphatase is involved in carbohydrate metabolism, growth and differentiation, protein synthesis, synthesis of certain enzymes, secretion activity, and transport to phosphorylated intermediates across the cell membranes ${ }^{22}$. The alkaline and acid phosphatase was enhanced during the toxic exposure period and under stress conditions. The elevated levels of phosphatases may indicate an increase in the rate of phosphorylation and transport of molecules across the cell membrane. As such, the enhanced phosphatases activity revealed an increase in the transportation of metabolites through the cellular membrane ${ }^{23}$, and it was reported that the pesticides cause significant increase in the cellular damage which enhanced the activity of phosphatases activity was altered in kupffermelanomacro phagic cells of Rana esculenta during environmental pollution. As such, they can utilize stored proteins to overcome toxic stress. During toxic stress, the levels of key enzymes involved in protein metabolism are changed. Cypermethrin reduced the DNA and RNA content in the gill, liver and kidney of fish Cirrhinus mrigala $^{24}$; Cypermethrin inhibiting the protein, glucose. ALP, ALT AST and LDH level in blood serum were increased in treated with cypermethrin intoxicating fish, detoxifying property of Cardiospermum halicacabum was noted ${ }^{25}$. The antioxidant enzyme of SOD, CAT and GPx level decreased and LPO level increased the control of plant Cardiospermum halicacabum can prevent or slow down the oxidative damage induced in fish Cirrhinus mrigala ${ }^{26}$. In the present study, $C$. halicacabum exposed acid and alkaline activity are recovered and regained its activity which may be change to the presence of important compounds like alkaloids, flavonoids, tannins and vitamin etc. $C$. halicacabum can prevent or slow down the oxidative damage induced in fish Cirrhinus mrigala ${ }^{26}$. Alkaloids are basic natural products occurring primarily in many plants. Alkaioids rank among the most efficient and therapeutically significant plant substances ${ }^{27}$. Some 5,500 alkaloids are known and they comprise the largest single class of secondary plant substances, which contain one or more nitrogen atoms, usually in combination as part of a cyclic structure. They exhibit marked physiological activity when administered to ${ }^{28}$. Furthermore, alkaloids are often toxic to man and many have dramatic physiological activities, hence their wide use in medicine for the development of drugs $^{25}$. Reviewed that, the antimicrobial property of tannins, which inhibitory activities of tannins up to that point ${ }^{29}$. According to these studies, tannins can be toxic to filamentous fungi, yeasts, and bacteria. Condensed tannins have been determined to bind cell walls of ruminal bacteria, preventing growth and protease activity ${ }^{30}$. Vitamin $\mathrm{K}$ is a complex naphthoquinone. Its anti hemorrhagic activity may be related to its ease of oxidation in body tissues. Hydroxylated amino acids may be made into quinones in the presence of suitable enzymes, such as a polyphenoloxidase ${ }^{31}$. Flavonoids are a group of phytochemicals found in varying amounts in foods and medicinal plants which have been shown to exert potent antioxidant activity against the superoxide radical $^{32}$. This may be as a result of its antioxidant activity and subsequent inhibitions of low-density lipoproteins (LDL) oxidation known to have been attributed to the dietary and supplemental intake of flavonoids and other micronutrients. Epidemiologic studies indicate an inverse relationship between intake of dietary flavonoids and coronary artherosclerotic disease $\mathrm{e}^{33}$. Flavonoids are 15-carbon compounds generally distributed throughout the plant kingdom. They are known to be synthesized by plants in response to microbial infection and have been found in vitro to be effective against a wide array of microorganisms. Flavone with the molecular formula, $\mathrm{C1}_{5} \mathrm{H}_{10} \mathrm{O}_{2}$, is a commonly found plant flavonoid ${ }^{34}$.

\section{CONCLUSION}

We conclude that the acid phosphatase and alkaline phosphatase levels in the fish organs gill liver and kidney are 
not represent good indices of the effect of cypermethrin in $C$. mrigala. Cypermethrin toxic effect was reduced in $C$. halicacabum feed fish. Leaves C. halicacabum may enhance the recovery of Phosphatase level.

\section{REFERENCES}

1. Bela zutshi and Raghu prasad SG. Impact of pollution on fresh and marine water resources. J Poll Res 2008; 27(3): 461-466.

2. Maruthanayagam C, Sharmila G. Haematobiochemical variations induced by the pesticide, Monocrotophos in Cyprinus carpio, during the exposure and recovery periods. Nat Environ Poll Tech 2004; 3: 491-494.

3. Oros DR, Hoover D, Rodigary R, Crane D, Sericano J. Levels and distribution of polybrominated diphenyl ethers in water, surface sediments and bivalves from the San Francisco Estuary. Environ Sci Tech 2005; 39: 33-41. http://dx.doi.org/10.1021/es048905q

4. Banaee M, Mirvagefei AR, Rafei GR and Majazi AB. Effect of sub lethal diazinon Concentrations on blood plasma biochemistry. Int. J. Env. Res 2005; 2: 189-198

5. Hassel KA. The biochemistry and uses of pesticides: Structure metabolism, mode of action and uses in crop protection, Macmillan Press, Basingstoke, UK; 1990. p. 536.

6. Luskova V, Svoboda M, Kolarova J. The effects of diazinon on blood plasma biochemistry of carp (Cyprinus carpio) Acta. Vet. Bron 2002; 71: 117-123. http://dx.doi.org/10.2754/avb200271010117

7. Almeida LC, Aguiar HL and Moraes G. Effect of methyl parathion on the muscle and brain acetylcholinesterase activity of matrinxã (Brycon cephalus). Ciencia Rural 2005; 35: 1412-1416. http://dx.doi.org/ 10.1590/S0103-84782005000600029

8. Prashanth MS, Neelagund SE. Impact of cypermethrin on enzyme activities in the freshwater fish Cirrhinus mrigala (Hamilton). Caspian J. Environ. Sci 2008; 6: 91-95.

9. Tejendra SG, Jaishree P, Hema Tiwari. Enzyme modulation by sub lethal concentrations of aldicarb, phosphamidon and endosulfan in fish tissues. Pestic. Biochem. Physiol 1990; 38: 231-244. http://dx.doi.org $/ 10.1016 / 0048-3575(90) 90095-J$

10. Mishra J, Srivastava A. Effect of chlordane on the blood and tissue chemistry of $H$. fossils. Cell. Mol. Biol 1984; 30: 51-524.

11. Owolabi MA, Coker HAP, Jaja SI. Flavonoid metabolites in urine after oral administration of the aqueous extract of Persea americana to rats. J. Nat. Med 2007; 61: 200-204. http://dx.doi.org/10.1007/s11418-0060122-7

12. Adesokan IA, Odetoyinbo BB, Olubamiwa AO. Bio preservative activity of lactic acid bacteria on suya produced from poultry meat. African Journal of Biotechnology 2008; 7: 3796-3800.

13. Tenniswood M, Bind CE, Clark AF. Phosphatases androgen dependent markers of rat prostrate. Can. J. Biochem 1976; 54: 340-343. http://dx. doi.org/10.1139/o76-051

14. Milton TS, Tsokos JO. Statistical methods in the biological and health science. Mc Graw - will. Internet Book comp; 1983. p. 381-405.

15. Boeger W, Ostrasky A, Guimaraes ATB, Romao S. Histophathology as an approach to evaluate the effect of the oil spill on fishes of the rivers Saldanha Barigui and Igvacu (Brazil). Int. Spill Conf 2003; 2(3): 100110.

16. Gabriel UU, George ADL. Plasma enzymes in C. gariepinus exposed to chronic levels of roundup (glyphosate). Environ and Ecology 2005; 23: 271-276.

17. Inyan IR, Daka ER, Ogamba EN. Effect of Diazinon on acid and alkaline phosphatase activities in plasma and organs of Clarias gariepinus. Curr Res J Biol Sci 2011; 191-194.

18. Das PC, Ayyappan S, Das BK, Jena JK. Nitrate toxicity in Indian major carp. Sub-lethal effect on selected enzymes in fingerlings of Catla catla, Labeo rohita and Cirrhinus mrigala. Comp Biochem Physiol Part C Toxicol Pharmacol 2004; 138: 3-10. http://dx.doi.org/10.1016/ j.cca.2004.03.010
19. Das BK, Mukherjee SC. Toxicity of Cypermethrin in Lebeo rohita fingerlings: biochemical enzymatic and hematological consequences. Comp Biochem Physiol Toxicol Pharmacol 2003; 134: 109-121. http:// dx.doi.org/10.1016/S1532-0456(02)00219-3

20. Anderson T, Forlin L, Hardig J, Larsson A. A physiological disturbance in fish living in coastal water polluted with bleached Kraft pulp mill effluents. Can J. Fish Aquat. Sci 2002; 45: 1525-1536. http://dx.doi. org/10.1139/f88-181

21. Arellano JM, Storch V, Saraquete C. Histological changes and copper accumulation in liver and gills of Senegales sole (Solea senegalesis). Ecotoxicol Environ. Safety 2004; 44: 62-67. http://dx.doi.org/10.1006 /eesa.1999.1801

22. Vijayavel K, Balasubramanian MP. Fluctuation of biochemical constituents and markers enzymes as a consequence of naphthalene toxicity in the edible estuarine carb Scylla serrata. Ecotoxicology and Environmental Safety 2006; 63: 141-7. http://dx.doi.org/10.1016 /j.ecoenv.2005.02.004

23. Venkateshwarlu P, Shobha RVJ, Janaiah C, Prasad MSK. Effect of Endosulfan and kelthane on hematology and serum biochemical parameters of the teleost, Clarias batuachus (Linn). Indian J. Comp. Anim. Physiol 1990; 8(1): 8-13.

24. Vasantharaja C, Pugazhendy K, Meenambal M, Prabakaran S, Nizar Ahmad Dar. Chelating properties of Cardiospermum halicacabum against the toxic effect of cypermethrin in the quatification of nucleic acid in the fresh water Cirrhinus mrigala (Hamilton). Int. Res. J. Pharm 2013; 4(1): 280-283

25. Vasantharaja C, Pugazhendy K, Meenambal M. Protective role of Cardiospermum halicacabum against the cypermethrin toxicity on the selected biochemical indices in serum activity in Cirrhinus mrigala (Hemilton). Journal of Pharmacy Research 2012; 5(5): 2595-2598.

26. Vasantharaja C, Pugazhendy K, Meenambal M, Prabakaran S, Venkatesan S, Jayanthi C. Protective role of Cardiospermum halicacabum against the cypermethrin toxicity in the oxidative stress in the fresh water fish Cirrhinus mrigala (hamilton). International Journal of Recent Scientific Research 2012; 3(7): 601 -606,

27. Okwu DE. Phytochemicals, Vitamins and Mineral contents of two Nigeria Medicinal plants. Int. J. Mol. Med. Adv. Sci 2005; 1(4): 375381 .

28. Okwu DE, Okwu ME. Chemical composition of Spondias mombin Linn. Plant parts. J. Sustain. Agric Environ 2004; 6 (2): 140-147.

29. Scalbert A. Antimicrobial properties of tannin. Phytochem 1991; 30: 3875-3883. http://dx.doi.org/10.1016/0031-9422(91)83426-L

30. Jones $\mathrm{CH}$, Kanamori H, Roecker SW. Missing roots and mantle drips Regional Pn and teleseismic arrival times in the southern sierra Nevada and vicinity, California, J Geophys. Res 1994; 99(33): 4567-4601. http://dx.doi.org/10.1029/93JB01232

31. Vamos Vigyazo L. Polyphenol oxidase and peroxidase in fruits and vegetables. CRC Crit. Rev. Food Sci. Nutr 1981; 15: 49-127. http://dx.doi.org/10.1080/10408398109527312

32. Hertog MGL, Feskens EJM, Hollman PC, Kantan MB, Krombhout D. Dietary antioxidant flavonoids and risk of coronary heart diseases; the Zutphen elderly study. Lncet 1993; 342: 007-1011.

33. Knekt P, Jarvinen R, Reunanen A, Maatela J. Flavonoid intake and coronary ortality in Finland: a cohort study. Br. Med. J 1996; 312: 478481. http://dx.doi.org/10.1136/bmj.312.7029.478

34. Martindale. The Extra Pharmacopoeia. $31^{\text {st }}$ edition. The Royal Pharmaceutical society, London, U.K; 1996.

\section{Cite this article as:}

Vasantharaja C, K. Pugazhendy, M. Meenambal. Studies on impact of cypermethrin on acid and alkaline phosphatase activity in the selected organs of fresh water fish Cirrhinus mrigala (Hamilton) and the protective effect of Cardiospermum halicacabum. Int. Res. J. Pharm. 2014; 5(9):667-670 http://dx.doi.org/10.7897/2230-8407.0509136 